\title{
PENGARUH PENGGUNAAN AUDIOVISUAL DAN MOTIVASI BELAJAR TERHADAP KETERAMPILAN BERBICARA BAHASA INGGRIS DI SMA NEGERI 3 TAKENGON
}

\author{
oleh \\ Alfi Syahrin* \& Amru bin As \\ *Dosen Program Studi Pendidikan Bahasa Indonesia, FKIP Universitas Al Muslim
}

\begin{abstract}
ABSTRAK
Penelitian ini bertujuan untuk menguji pengaruh audiovisual dan motivasi siswa terhadap keterampilan berbicara bahasa Inggris. Populasi penelitian ini adalah siswa SMA Pegasing Takengon-Aceh Tengah. Sampel diambil 125 siswa kelas dua. Data penelitian ini diambil melalui pengaruh motivasi belajar siswa dalam pembelajaran keterampilan berbicara dan hasil rapor siswa kelas dua semester dua. Hasil analisis menunjukkan bahwa terdapat pengaruh yang signifikan (f hitung 5,050 dan $\mathrm{p}<0,050$ ) motivasi siswa terhadap keterampilan berbicara bahasa Inggris.
\end{abstract}

Kata Kunci: Pengaruh, audiovisual, motivasi, keterampilan berbicara bahasa Inggris.

\section{PENDAHULUAN}

Bahasa memiliki peran sentral dalam perkembangan intelektual, sosial, dan emosional peserta didik dan merupakan penunjang keberhasilan dalam mempelajari semua bidang studi. Pembelajaran bahasa diharapkan membantu peserta didik mengenal dirinya, budayanya, dan budaya orang lain. Selain itu, pembelajaran bahasa juga membantu peserta didik mampu mengemukakan gagasan dan perasaan, berpartisipasi dalam masyarakat, dan bahkan menemukan serta menggunakan kemampuan analitis dan imaginatif yang ada dalam dirinya.

Bahasa Inggris merupakan alat untuk berkomunikasi secara lisan dan tulis. Berkomunikasi adalah memahami dan mengungkapkan informasi, pikiran, perasaan, dan mengembangkan ilmu pengetahuan, teknologi, dan budaya. Kemampuan berkomunikasi dalam pengertian yang utuh adalah kemampuan berwacana, yakni kemampuan memahami dan/atau menghasilkan teks lisan dan/atau tulis yang direalisasikan dalam empat keterampilan berbahasa, yaitu mendengarkan, berbicara, membaca dan menulis. Keempat keterampilan inilah yang digunakan untuk menanggapi atau menciptakan wacana dalam kehidupan bermasyarakat. Oleh karena itu, mata pelajaran Bahasa Inggris diarahkan untuk mengembangkan keterampilanketerampilan tersebut agar lulusan mampu berkomunikasi dan berwacana dalam bahasa Inggris pada tingkat literasi tertentu.

Tingkat literasi mencakup performative, functional, informational, dan epistemic. Pada tingkat performative, orang mampu membaca, menulis, mendengarkan, dan berbicara dengan simbol-simbol yang digunakan. Pada tingkat functional, orang mampu 
menggunakan bahasa untuk memenuhi kebutuhan hidup sehari-hari seperti membaca surat kabar, manual atau petunjuk. Pada tingkat informational, orang mampu mengakses pengetahuan dengan kemampuan berbahasa, sedangkan pada tingkat epistemic orang mampu mengungkapkan pengetahuan ke dalam bahasa sasaran (Wells, 1987).

Pembelajaran bahasa Inggris di SMP/MTs ditargetkan agar peserta didik dapat mencapai tingkat functional yakni berkomunikasi secara lisan dan tulis untuk menyelesaikan masalah sehari-hari, sedangkan untuk SMA/MA diharapkan dapat mencapai tingkat informational karena mereka disiapkan untuk melanjutkan pendidikannya ke perguruan tinggi. Tingkat literasi epistemic dianggap terlalu tinggi untuk dapat dicapai oleh peserta didik SMA/MA karena bahasa Inggris di Indonesia berfungsi sebagai bahasa asing.

Sesuai dengan Kurikulum Tingkat Satuan Pendidikan (Diknas 2006) Mata Pelajaran Bahasa Inggris di SMA/MA bertujuan agar peserta didik memiliki kemampuan sebagai berikut:

1. Mengembangkan kompetensi berkomunikasi dalam bentuk lisan dan tulis untuk mencapai tingkat literasi informational.

2. Memiliki kesadaran tentang hakikat dan pentingnya bahasa Inggris untuk meningkatkan daya saing bangsa dalam masyarakat global.

3. Mengembangkan pemahaman peserta didik tentang keterkaitan antara bahasa dengan budaya.

Luar biasa, bahwa bahasa Inggris menjadi kebanggan tersendiri bagi seorang siswa yang mampu menguasai sekaligus mampu juga berbicara bahasa Inggris dengan baik sesuai menurut tingkat kelas seseorang yang tersebut diatas. Bagi siswa yang duduk di kelas 1 SMP tentu mereka hanya bisa berbicara bahasa Inggris pada tingkat greetings tentu sangat membagakan sekali karena sesuai menurut levelnya sementara bagi siswa SMA mereka mampu menguasai dan berbicara bahasa Inggris atau mampu mengulas kembali yang bersangkutan dengan mata pelajaran yang ada dalam kelas secara keseluruhan dengan baik dan benar. Siswa tersebut juga mampu menjelaskannya bukan saja kepada kawan-kawan didalam kelasnya bahkan lebih dari itu, mereka mampu berbicara bahasa Inggris dengan guru-guru bahasa bahasa Inggrisnya baik dikelas atau diluar kelas.

Penguasaan bahasa Inggris, pada prinsipnya tidaklah terlalu sulit bagi semua siswa atau masyarakat belajar, cukup hanya dengan kemauan tinggi untuk mempelajarinya dan mempraktikannya dengan lawan berbicara atau sering melatih diri dengan berbagai buku baru, majalah, iklan, tulisan-tulisan yang ada di media. Cukup dilakukan secara sederhana sekali misalnya: membaca dan menguasai kosa kata bahasa Inggris sebanyak lima kosa kata setiap hari dengan hal-hal yang baru. Setelah itu dipraktikan ucapan-ucapan sesuai dengan pronunciation yang benar.

Memang benar bahwa guru sebagai fasilitator yang baik untuk menyampaikan pesan-pesan yang baik terhadap siswa. Kepandaian siswa tidak pernah terlepas dari teaching learning model of teacher ( Gordon, 2000) karena guru yang baik adalah mampu mengubah sikap dan perilaku siswa dari yang belum bisa menjadi dapat berbuat, dari yang tidak tahu menjadi menguasai, dan bahkan guru mampu merubah nasib siswa dari kesulitan ekonomi menjadi komplit dalam bidang materi melalui ilmu pengetahuan yang disampaikan kepada siswa tersebut. Dengan demikian dapat dikatakan bahwa guru sebagai salah contoh fasilitas pembelajaran yang sempurna bagi siswa. Keteladanan seorang guru akan menjadi sumber insprasi keberhasilan siswa terutama dalam proses pembelajaran 
semua pelajaran khususnya bidang studi bahasa Inggris yang peneliti gambarkan diatas.

Guru sering menjadi sorotan dari berbagai pihak, terutama dari masyarakat yang tinggal di sekitar sekolah karena kurang mampu membina anak didik kearah yang lebih bagus. Dengan kata lain, nilai yang diinginkan orang tua dan murid bahkan lebih dari itu didalam setiap Ujian Nasional dimana beberapa mata pelajaran selalu anjelok tidak sesuai dengan harapan standar pencapaian nasional (Kompas, 2007). Mungkin materi ajar yang diberikan guru kepada peserta didik terlalu sulit, terlalu mudah, tidak sesuai kurikulum, tidak sesuai tuntutan kekinian, lemahnya fasilitas pembelajaran seperti media belajar atau bahkan karena rendahnya motivasi siswa terhadap mata pelajaran bahasa Inggris itu sendiri.

Akan tetapi, dalam penelitian yang dilakukan peneliti ini adalah bukan menyangkut secara keseluruhan subtopic materi bahasa Inggris (listening, reading, speaking, dan writing) akan tetapi peneliti hanya membatasi sub yang tertentu. Sebagaimana peneliti gambarkan diatas adalah berhubungan dengan motivasi siswa terhadap keterampilan berbicara dalam bahasa Inggris. Ya atau tidak, belajar berbicara dalam bahasa asing memang sungguh dirasa sulit disebabkan bukan bahasa sendiri (Lisna, 2006). Keterampilan berbicara yang dilakoni pembelajar membutuhkan step-step khusus yang harus dilalui dengan berbagai pola, aturan dan bahkan tata kerama saat berbicara sehingga terasa bagi siswa bahwa melakukan berbicara bahasa asing adalah sulit apalagi proses pembelajaran keterampilan itu tanpa dibantu dengan alat bantu pelajaran sehingga menambah sulit untuk diajarkan.

Fenomena yang terjadi di berbagai lembaga pendidikan mulai dari siswa tingkat SLTP bahkan sampai kepada tingkat mahasiswa di Perguruan Tinggi sekalipun hanya sedikit sekali yang mampu berbicara bahasa Inggris. Yang lebih ekstrem lagi adalah adanya guru mata pelajaran bahasa Inggris sendiri yang tidak bisa berbicara bahasa Inggris didepan siswanya atau sesama guru bahasa Inggris. Fenomena ini adalah sebuah kemungkinan yang terjadi sehingga banyak jumlah siswa yang enggan berbicara bahasa Inggris baik dengan rekan sekelas maupun diluar itu. Peneliti merasa yakin bahwa keterampilan berbicara bahasa Inggris bagi siswa seluruh Indonesia hanya sedikit sekali khususnya ditempat penelitian yang peneliti lakukan ini.

Atau boleh jadi, guru bahasa Inggris hanya mengajarkan bidang studi ini (keterampilan) ini dengan metode hafalan saja dengan merujuk ke teori-teori lama dan materi sedanya, prose pembelajaran dilakukan hanya berupa manual tanpa menggunakan media (audiovisual) sehingga selalu melakukan dengan ucapan-ucapan mulut belaka dimana guru mampu mendikte bahasa Inggris sementara siswa hanya mendengar dan menulis. Fenomena inilah yang menyebabkan rendahnya motivasi keterampilan berbicara bahasa Inggris sehingga kebanyakan diantara siswa SMA Negeri 3 Takengon hanya 3 orang saja yang bisa berbicara bahasa Inggris diantara 289 siswa.

Ketidak mampuan seorang guru bahasa Inggris membawa siswanya untuk meningkatkan motivasi berbahasa Inggris berarti kelemahan seorang yang tidak memperkaya diri dengan berbagai fasilitas yang ada (Muh. Ansyar Jalius Jamma, 2007). Kegiatan guru dalam mengajarkan materi bahasa Inggris tidak terlepas dengan system konvensional belaka yang hanya memberi muatan kognitif saja.

Memperkaya siswa dengan ribuan kosa kata dan disuruh menghafal beberapa tenses yang ada dalam grammar bahasa Inggris sehingga membuat siswa monoton alias kondisi kelas mati suri, tidak ditampilkan dengan media-media untuk 
membangkitkan motivasi belajar, padahal tuntutan dari kurikulum bahasa Inggris baik dalam KBK (2004) dan KTSP (2006) adalah mengajak siswa aktif dalam melakukan dan menyelesaikan permasalahan yang ada dalam setiap pelajaran khususnya pelajaran bahasa Inggris. Pantas kalau pelaksanaan Ujian Nasional siswa mendapat supply tanpa bunga yang terus mengalir saat pelaksanaan Ujian Nasional selama beberapa hari baik dari guru maupun tim sukses yang telah terbentuk kian rapi di setiap lembaga pendidikan SLTP, MTs, SMA, MA dan lain-lain. Tidak cukup disana, bantuan gratis juga didapatkan di rayon-rayon dengan alasan bahwa apabila sekolah ini dan itu tingkat kelulusannya rendah maka bantuan dari Pemda akan berkurang bahkan kepala sekolah bisa dimutasikan ketempat yang agak kering atau dikembalikan kepada guru biasa. Fenomena lapangan telah terjadi seperti ini sehingga guru-guru setiap bidang studi melakukan supply bantuan kepada seluruh siswa.

Menyangkut dengan media belajar yang berdampak terhadap motivasi belajar siswa terhadap keterampilan berbicara bahasa Inggris juga masih sangat minim dijumpai disekolah. Pada sekolah tempat penelitian ini berlangsung kesediaan tape recorder hanya ada satu unit sementara guru bahasa Inggris ada 5 orang dengan jumlah kelas sebanyak 20 kelas: kelas satu berjumlah 7 kelas paralel; kelas dua berjumlah 7 kelas paralel dan kelas tiga berjumlah 6 kelas yang terdiri dari jurusan IPA-IPS. Mengenai laboratorium bahasa masih jauh dari bayangan. Dari kasus satu unit tape recorder timbul pertanyaan "apakah mungkin dua atau tiga kelas dengan waktu yang bersamaan fasilitas audio visual atau tape recorder itu dapat dipakai”. Hal yang mustahil, dari gambaran itu dapat dikatakan bahwa empat orang guru bahasa Inggris sudah pasti mengajar dengan menggunakan strtategi yang bersifat konvensional alias model klasik. "Kapan siswa itu dapat ditingkatkan motivasinya sementara alat Bantu yang sangat terbatas sekali?"

Sehubungan dengan gambaran diatas, menurut Kasbolah (1990) bahwa fasilitas yang dibutuhkan dalam proses pembelajaran bahasa Inggris masih belum memadai termasuk seperti buku-buku pelajaran yang terkait, rekaman kaset atau vedio, laboratorium bahasa, hamper tidak ada penutur asli yang mau memberikan motivasi kedalam kelas sehingga kemauan siswa nampak lemah. Adnan (1986) menyatakan bahwa keberadaan guru bahasa Inggris yang qualified juga masih terbatas terutama di sekolahsekolah yang terpencil, menjadi masalah yang rumit dan tidak mudah untuk diatasi dalam rangka peningkatan mutu pembelajaran bahasa Inggris.

Selain itu, ada hal-hal penting untuk diperhatikan bahwa dari sisi teori belajar bahasa Inggris pada umumnya siswa adalah pemakai bahasa ibu akan menerima bahasa Inggris bukan sebagai bahasa asing (Baraja dalam Tubagyo, 1994). Di tingkat SMA mata pelajaran bahasa Inggris masih banyak diajarkan dengan metode hafalan sehingga pembelajaran bahasa Inggris masih dirasakan sulit dan membosankan bagi anak didik (Moh. Ansyar, 2007). Dalam hal ini, guru lebih banyak menempatkan siswa sebagai objek dan bukan sebagai subyek didik kurang memberikan kesempatan kepada siswa dalam berbagai mata pelajaran khususnya mata pelajaran bahasa Inggris untuk mengembangkan berfikir siswa secara holistic, kreatif, objektif dan logis.

Seorang guru bahasa Inggris perlu kembali memperbaiki cara mengajarnya. Pelaksanaan proses belajar mengajar tidak saja didukung oleh strategi dan pendekatan (approach) pembelajaran yang bervariasi disesuaikan dengan karakteristik siswa, namun juga perlu memanfaatkan sumber-sumber belajar dan media pembelajaran. Banyak faktor 
yang diduga dapat mempengaru motivasi siswa untuk mengembangkan keterampilan berbicara bahasa Inggris di SMA Negeri Pegasing, antara lain ialah: memperbaiki strategi pembelajaran, motivasi belajar siswa, kemampuan guru dalam mendisaen pembelajaran berbicara bahasa Inggris, lingkungan dan iklim belajar serta media pembelajaran yang spesifik.

Sesungguhnya, media pembelajaran akan memberikan kemudahan bagi siswa untuk menyerap materi keterampilan berbicara bahasa Inggris yang disampaikan guru. Siswa lebih termotivasi apabila pelajaran diberikan dengan membawa siswa kedalam dunia realia yang konkrit. Sesuai dengan kematangan siswa SMA kelas dua, penggunaan media audiovisual maka sangat bermanfaat dalam membantu siswa dalam proses belajar mengajar, lebih baik lagi jika siswa dilibatkan dalam penggunaan dan pemanfaatan media yang ada di sekolah.

Sekolah-sekolah yang ada di kabupaten Aceh Tengah khususnya pada tingkat SLTA bukannya tidak ada media pembelajaran/ ada pada tingkat minimal akan tetapi guru-guru yang mengajar berbicara bahasa Inggris merasa kurang tertantang untuk menggunakan media yang ada disekolah, alangkah baiknya para siswa dibawa ke sekolah lain yang memiliki laboratorium bahasa, atau siswa dibawa ke tempat pariwisata terdekat yang mana orang-orang asing berkumpul disana. Dengan cara demikian, maka rangsangan motivasi siswa akan menjadi lebih tinggi karena mereka (siswa) berhadapan dengan media yang realia. Disamping itu, dalam mendisaen pembelajaran, guru-guru jarang mempertimbangkan aspek media dalam perancangan pembelajaran dengan menggunakan bantuan media audiovisual. Sebaiknya guru-guru bahasa Inggris sebaiknya mampu dan harus menggunakan media pembelajaran dengan sebaik mungkin agar peserta didik dapat menyentuh dan menguasai keterampilan berbicara bahasa Inggris dalam bentuk bantuan. Pemilihan dan penggunaan media harus mempedomani tujuan pembelajaran yang akan dicapai, karakeristik siswa, dan lingkungan belajar siswa.

Berdasarkan gambaran diatas, maka banyak faktor-faktor yang mempengaruhi siswa untuk termotivasi sehingga senang belajar keterampilan berbicara bahasa Inggris . adapun faktorfaktor tersebut berasal dari dalam diri dan dari luar diri siswa tersebut. Dari dalam diri siswa ialah seperti: biologis yang meliputi usis, kematangan berfikir, kesehatan dan lain-lain. Sementara faktor luar diri siswa adalah faktor keluarga yang terdiri dari: suasana rumah tangga, keadaan ekonomi orang tua, latar belakang kebudayaan yang sama dan berbeda.

Termasuk juga sebagai faktor luar yang lain adalah faktor sekolah yang meliputi: strategi pembelajaran yang disajikan oleh guru mata pelajaran (Agustiarsyahnur), metode mengajar keterampilan bahasa Inggris (Zainil, 2008), kurikulum pendidikan bahasa Inggris yang sesuai dengan kekinian dengan sebutan hi-tech (Muh. Ansyar, 2007), relasi guru-siswa yang harmonis dengan sebutan high-touch (Prayitno, 2007), disiplin sekolah, media pembelajaran yang sesuai dengan bidang studi ajar untuk membawa siswa benarbenar aktif untuk melatih diri dalam keterampilan berbicara bahasa Inggris (Adri, 2007) dan lain sebagainya. Akhirnya, faktor masyarakat yang meliputi: apa kegiatan siswa yang dilakukannya ditengah-tengah masyarakat sekitar sekolah, siapa teman bergaul di rumah, dan lain-lain.

Faktor media pembelajaran (audiovisual) dan motivasi belajar keterampilan berbicara bahasa Inggris diduga adalah paling kuat mempengaruhi 
keterampilan berbicaranya karena setiap kesulitan yang dihadapi siswa saat belajar maka terbantu dengan media yang ada sehingga kecil kemungkinan bagi peserta didik tidak termotivasi. Media yang dipergunakan dalam penelitian ini ialah media audiovisual yakni CD tentang bagaimana orang asing dan orang pribumi (guru, siswa, masyarakat, pegawai, buruh dan lain-lain) berbicara bahasa Inggris. Mereka ditunjukkan dilayar LCD sehingga nampak dilihat secara keseluruhan kegiatan-kegiatan yang berhubungan dengan latihan berbicara bahasa Inggris.

Jadi, penggunaan media tersebut dapat menimbulkan semangat dalam diri siswa untuk berlatih keterampilan berbicara bahasa Inggris sehingga produknya nampak dimata masyarakat sekolah adanya. Sementara pada motivasi belajar dibatasi pada indikatornya: a) ketertarikannya terhadap penyampaian guru bidang studi bahasa Inggris, b) tertarik pada bidang studi bahasa Inggris, c) memiliki antusias tinggi untuk berbicara bahasa Inggris, d) mengingat dan berlatih kembali tentang model percakapan yang nampak dalam tayangan lalu, e) ingin selalu bergabung dengan kelompok diskusi kecil untuk berlatih dan menguji coba percakapan bahasa Inggris, f) keinginan pribadi siswa sebagai identitas diri hendanya diakui. Dengan demikian, motivasi siswa tersebut bangkit lebih tinggi sehingga dalam melakukan training English speaking skills aktif dan berperan serta dalam pembelajaransehingga hasil yang akan diperoleh dapat meningkat baik. Demikian juga motivasi rendah akan beroleh hasil yang minim alias kurang diharapkan oleh pengguna artinya apabila seseorang mampu melakukan keterampilan berbicara bahasa Inggris yang bagus tentu siswa tersebuta akan terpakai tenaganya sebagai juru bicara bagi orang asing dengan pengahasilan lumayan.
Jadi, gambaran diatas, maka peneliti dibawah ini merumuskan masalah penelitian sebagai berikut: a) bagaimana pengaruh penggunaan media audio visual terhadap keterampilan berbicara bahasa Inggris yang dilakukan siswa didalam kelas jauh lebih bagus dari pada menggunakan metode konvensional?, apakah hasil keterampilan berbicara bahasa Inggris kelompok siswa dengan motivasi belajar tinggi yang diajarkan dengan menggunakan media audio visual lebih tinggi dari pada kelompok yang diajar dengan metode konvensional?, apakah hasil keterampilan berbicara bahasa Inggris dengan motivasi belajar rendah diajar dengan menggunakan media audio visual lebih tinggi dari pada dengan metode konvensional?, dan apakah terdapat interaksi antara penggunaan media audio visual dengan motivasi belajar terhadap hasil belajar pada pelajaran bahasa Inggris dengan subtopic keterampilan berbicara bahasa Inggris.

Sehubungan dengan kajian diatas, maka penelitian ini diharapkan bermanfaat bagi pemerhati terhadap pendidikan terutama guru yang mengajar bidang studi bahasa Inggris, siswa yang belajar bahasa Inggris, orang tua yang senang anaknya mampu berbahasa Inggris, dan para pakar pendidikan. Setelah terbukti bahwa ada pengaruh media audiovisual terhadap motivasi siswa untuk meningkatkan keterampilan berbicara bahasa Inggris maka faktor tersebut hendaknya menjadi perhatian dan pertimbangan oleh pemerhati pendidikan sebagai perbaikan cara peningkatan keterampilan berbicara khususnya bahasa Inggris. Hasil penelitian ini dapat dijadikan sebagai informasi tentang halhal yang dapat dilakukan oleh pemerhati pendidikan dalam rangka membentuk pengaruh media audiovisual yang positif terhadap pengajaran bagi peningkatan motivasi belajar bahasa Inggris pada siswa terutama siswa tingkat SMA. 


\section{METODE PENELITIAN}

Variabel dalam penelitian terdiri dari variabel bebas pertama yaitu media pembelajaran berupa penggunaan audio visual terhadap proses pembelajaran keterampilan berbicara bahasa Inggris. Sementara variabel bebas adalah motivasi siswa kelas dua SMA dalam mempelajari keterampilan berbicara bahasa Inggris sebagai bahasa asing kedua yang wajib dipelajari di sekolah-sekolah mulai dari tingkat SLTP sampai ketingkat Perguruan Tinggi (PT). Adapun variabel ini berfungsi untuk mengelompokkan siswa menjadi dua kelompok yakni kelompok siswa yang bermotivasi tinggi dan rendah sementara variabel terikat adalah hasil peroses belajar mengajar pelajaran bahasa Inggris dalam hal ini dengan subtopik keterampilan berbicara bahasa Inggris.

Jenis penelitian ini quasi eksperimen yang menggunakan dua kelas yakni kelas eksperimen dan kelas kontrol. Kelas eksperimen diberikan perlakuan dengan menggunakan media pembelajaran berupa audio visual dalam PBM terhadap keterampilan berbicara bahasa Inggris sementara pada kelas kontrol tidak diberikan perlakuan seperti pada kelas eksperimen namun kedua kelas tersebut diberikan materi yang sama. Penelitian dilaksanakan di SMA Negeri 3 Takengon Kabupaten Aceh Tengah sejak bulan Agustus sampai dengan bulan Oktober 2019.

Penelitian eksperimen mencoba untuk meneliti ada tidaknya hubungan sebab akibat dengan membandingkan satu atau lebih kelompok eksperimen yang diberikan perlakuan khusus yakni dengan menggunakan audio visual, dalam penyajian mata pelajaran bahasa Inggris pada subtopik keterampilan berbicar (speaking skill) dengan kelompok lain yang tidak diberikan perlakuan khusus seperti yang diatas akan tetapi diperlakukan dengan metode konvensional. Penelitian ini dilakukan selama beberapa kali pertemuan oleh guru mata pelajaran bahasa Inggris dengan rincian; pertemuan pertama dilakukan untuk melihat gambaran tentang penggunaan media audio visual dalam PBM.

Adapun pengumpulan data, peneliti melakukan tes keterampilan berbicara bahasa Inggris untuk mendapatkan gambaran hasil belajar siswa dalam bidang berbicara dengan menggunakan media audio visual dan yang tidak menggunakan media (kelas kontrol). Tes disusun dengan kompetensi dasar dan pokok bahasan yang dieksperimenkan. Kompetensi dasar yang diujikan adalah kemampuan siswa dalam percakapan bahasa Inggris.

Adapun indikator yang harus dicapai siswa adalah: menggunakan kosa kata, ketepatan ucapan bahasa Inggris, menjelaskan dan menjawab pertanyaan yang dipertanyakan oleh lawan bicara bahasa Inggris, menggunakan struktur yang benar, dan lain-lain. Selanjutnya, instrumen penelitian ini menggunakan tes lisan keterampilan berbicara bahasa Inggris yang menggunakan media audio visual instrumen tes hasil disusun berdasarkan Tujuan Instruksional Khusus dari materi yang dieksperimenkan. Sementara untuk motivasi siswa digunakan angket yang disusun dalam bentuk kisi-kisi berdasarkan indikatorindikator kemudian dituangkan dalam bentuk pernyataan. Angket diberikan skor melalui skala Likert.

\section{HASIL PENELITIAN}

Deskripsi data penelitian ini adalah meliputi variabel motivasi belajar siswa secara keseluruhan yang mengungkapkan informasi tentang skor total, skor tertinggi, skor terendah, rerata, stanfdar deviasi, modus dan medium. Adapun profil data diatas dapat digambarkan dalam data dibawah ini sebagai berikut: 
Deskripsi Data Motivasi Belajar Keseluruhan

\begin{tabular}{|c|c|c|c|c|c|c|c|}
\hline No & Statistik & $\begin{array}{c}\text { Motivasi } \\
\text { Belajat Kel. }\end{array}$ & $\begin{array}{c}\text { Motivasi } \\
\text { Belajat }\end{array}$ & \multicolumn{2}{|c|}{$\begin{array}{l}\text { Motivasi Belajar } \\
\text { Kel. Eksperimen }\end{array}$} & \multicolumn{2}{|c|}{$\begin{array}{c}\text { Motivasi Belajar } \\
\text { Kel. Kontrol }\end{array}$} \\
\hline & & & & Tinggi & Rendah & Tinggi & Rendah \\
\hline 1 & Skor Total & 5585 & 5106 & 1674 & 1451,5 & 1563,5 & 1290 \\
\hline 2 & Skor & 194 & 190 & 194 & 169 & 190 & 151 \\
\hline 3 & Ter.Tgg & 150 & 136 & 180 & 150 & 166 & 36 \\
\hline 4 & Skor Trndh & 174,53 & 161,25 & 186 & 161,28 & 173,72 & 143,33 \\
\hline 5 & Rerata & 10,03 & 11,67 & 3,97 & 5,69 & 6,18 & 4,85 \\
\hline 6 & Stndr Dvs & 173,23 & 161,9 & 186,5 & 159,5 & 175,5 & 143,7 \\
\hline 7 & $\begin{array}{l}\text { Modus } \\
\text { Media }\end{array}$ & 174,25 & 160,25 & 160,83 & 160,83 & 176,33 & 144 \\
\hline
\end{tabular}

Data deskripsi motivasi kelompok eksperimen (A1) meliputi: mean sd 174,53; skor maksimum ideal $=200$; standar deviasi $=10,03$; variansi $=100,52$; modus $=173,23$; dan median $=174,25$. Data deskripsi motivasi kelompok kontrol (A2) meliputi: mean sd 161,25; skor maksimum ideal $=200$; standar deviasi $=11,67$; variansi $=136,11$; modus $=161,9 ;$ dan median $=160,25$. Deskripsi data kelompok siswa yang memiliki motivasi tinggi yang diajarkan dengan media audio visual (A1B1) meliputi: mean $=186$; skor maksimum ideal $=200$; standar deviasi sd 3,97; variansi $=15,75$; modus $=186,5$ dan median $=186$. Deskripsi data kelompok siswa yang memiliki motivasi rendah yang diajarkan dengan media audio visual (A1B2) meliputi: mean $=161$ skor maksimum ideal $=200 ;$ standar deviasi $=5,69$; variansi $=32,41 ;$ modus $=159,5$ dan median $=160,83$. Deskripsi data kelompok siswa yang memiliki motivasi belajar tinggi yang diajarkan tanpa media audio visual (A2B1)) meliputi: mean = 173,72 skor maksimum ideal $=200$; standar deviasi $=61,8$; variansi $=38,16$; modus sd 175,5 dan median $=176,33$. Deskripsi data kelompok siswa yang memiliki motivasi belajar rendah yang diajarkan dengan tanpa media audio visual (A2B2) meliputi: mean $=46,43$ skor maksimum ideal $=100$; standar deviasi $=8,76$; variansi $=76,68$; modus $=46,38$ dan median $=46,38$.

\section{PEMBAHASAN}

Dari hasil perhitungan dapat diperoleh hasil selisih rerata lebih besar dari nol, maka bisa disimpulkan bahwa terdapat interaksi antara penggunaan media audio visual dalam proses pembelajaran bahasa Inggris pada sub topik keterampilan berbicara bahasa Inggris dan motivasi belajar siswa khususnya pada keterampilan berbicara (speaking skill). Baik kelompok siswa yang memiliki motivasi tinggi dan rendah apabila diajarkan dengan alat bantu belajar audio maka hasil keterampilan berbicara mereka akan menjadi lebih.

Media pembelajaran sebagai alat Bantu dalam pembelajaran berfungsi sebagai penghantar materi pembelajaran kepada peserta didi. Hal ini jelas, bahwa dengan menggunakan media audio visual maka materi pembelajaran cepat sampai kepada siswa dan dapat dipahaminya dengan baik. Media dalam pembelajaran, khususnya audio visual adalah suatu kenyataan yang tidak dapat dipungkiri, 
karena gurulah yang menghendakinya dalam rangka membantu tugas guru untuk menyampaikan pesan-pesan dari bahan pelajarn yang diberikan guru kepada peserta didik. Guru menyadari bahwa tanpa bantuan media dalam PBM maka akan sulit bagi siswa melakukan keterampilan berbicara bahasa Inggris dengan cepat.

Sesuai dengan hasil penelitian yang dilakukan oleh Masrifahidayani (2006) tentang pengaruh penggunaan media audio visual terhadap pembelajaran bahasa Arab STAIN Bengkulu menemukan bahwa bantuan media audio visual ternyata sangat efektif dalam meningkatkan hasil belajar siswa sekaligus meningkatkan motivasi siswa dalam melakukan keterampilan berbicara bahasa Inggris. Dalam usaha memanfaatkan media sebagai alat Bantu Edgar Dale (dalam Sadiman, 1996) mengklasifikasikan pengalaman menurut tingkat dari yang paling konkrit sampai kepada yang abstrak yakni pengalaman langsung, observasi, partisipasi, demonstrasi, wisata, TV, film, radio, visual, simbol visual dan verbal. Dalam penggunaan media audiovisual dalam pembelajaran di samping meningkatkan motivasi belajar siswa dalam pembelajaran juga bermanfaat dalam meningkatkan prestasi dan hasil belajar tentang keterampilan berbicara bahasa Inggris sehingga dapat digunakan secara efektif mungkin dalam meningkatkan keterampilan berbicara bahasa Inggris.

Berdasarkan gambaran diatas, penelitian ini masih memperlihatkan keterbatasan-keterbatasan seperti: penelitian ini hanya dilakukan pada siswa kelas dua SMA Negeri 3 Takengon sehingga belum dapat dilakukan generalisasi kepada kelas lain yang paralel karena sample penelitian belum mewakili keseluruhan karakteristik dari populasi; hasil penelitian yang dilakukan ini hanya dilihat dari dua sisi saja yakni: 1) pengaruh penggunaan media audio visual dan 2) motivasi siswa terhadap proses pembelajaran keterampilan berbicara bahasa Inggris sementara hal-hal lain yang dianggap dominan untuk mempengaruhi proses pembelajaran keterampilan berbicara bahasa Inggris; walaupun instrumen penelitian telah memiliki validitas dan reliabilitas yang tinggi, namun instrument tersebut baru mengukur hasil belajar siswa tentang keterampilan berbicara bahasa Inggris dan belum dapat mengukur hasil belajar bahasa Inggris secara integritas.

\section{PENUTUP}

Berdasarkan hasil temuan dilapangan maka dapat disimpulkan bahwa hasil belajar siswa dalam bidang keterampilan berbicara bahasa Inggris yang diajarkan dengan menggunakan alat bantu audio visual lebih tinggi dari pada hasil belajar siswa yang diajar dengan metode knovensional. Penggunaan audio visual juga dapat meningkatkan motivasi belajar siswa dalam pembelajaran sehingga siswa terlibat langsung secara aktif, kreatif, efektif dan menyenangkan. Hasil penelitian in juga menunjukkan terdapat interaksi antara penggunaan alat bantu mengajar berupa audio visual dan motivasi belajar terhadap hasil belajar siswa.

Hasil yang dapat diperoleh dalam penelitian ini dapat dijadikan masukan bagi guru-guru terutama guru bahasa Inggris. Berdasarkan kesimpulan diatas, dapat diketahui bahwa penggunaan audio visual dalam pembelajaran keterampilan berbicara bahasa Inggris cukup efektif dalam meningkatkan motivasi hasil belajar bahasa Inggris. Oleh karena itu, dalam proses pembelajaran setiap guru khususnya guru bahasa Inggris perlu memilih dan mempertimbangkan jenisjenis media audiovisual yang akan disajikan dalam menyampaikan materi pembelajaran terhadap siswa sehingga pembelajar dengan mudah dapat memahami dan menguasai keterampilan 
berbicara bahasa Inggris selanjutnya dapat mereka praktikkan dalam percakapan sehari-hari dengan lancar. Sebagai tujuan proses pembelajaran adalah memberi jalan untuk memudahkan pembelajar untuk berkomunikasi dalam bahasa asing dengan sempurna.

Guru sebagai ujung tombak pendidikan yang mampu menggerakkan mutu pendidikan dan memotivasi peserta didik sehingga bisa mengubah perilaku siswa menjadi baik. Dengan demikian, guru sebaiknya melengkapi dirinya dengan berbagai fasilitas mengajar untuk memudahkan siswa mengikuti pembelajaran dan membuat iklim kelas menjadi hidup.

Dalam hal ini terutama kepada
guru-guru yang pembelajaran bahasa Inggris agar mampu memberikan kemudahan dan sanggup memotivasi anak didik untuk mengembangkan keterampilan berbicara bahasa Inggris dengan cara menggunakan alat bantu pembelajaran berupa audiovisual. Penggunaan alat bantu tersebut dapat dilakukan dengan cara memanfaatkan pusat belajar, perpustakaan, LPM dan pustekom dalam menjalin kerjasama dalam penyediaan CD atau fasilitas pembelajaran untuk mata pelajaran yang menyangkut dengan keterampilan berbicara bahasa Inggris. Sebaiknya, guru memperhatikan perbedaan dan karakteristik siswa dalam pembelajaran yang diberikan sehingga pemilihan media pembelajaran disesuaikan dengan karakteristik siswa yang ada. Selanjutnya, guru harus melibatkan semua siswa dalam proses pembelajaran dengan menggunakan media audiovisual demi meningkatkan hasil belajar siswa dalam bidang keterampilan berbicara bahasa Inggris. Akhirnya, kepada peneliti selanjutnya dapat menggunakan sample yang lebih besar sehingga didapatkan data yang sempurna dan akurat tentang penggunaan media audiovisual.
DAFTAR PUSTAKA

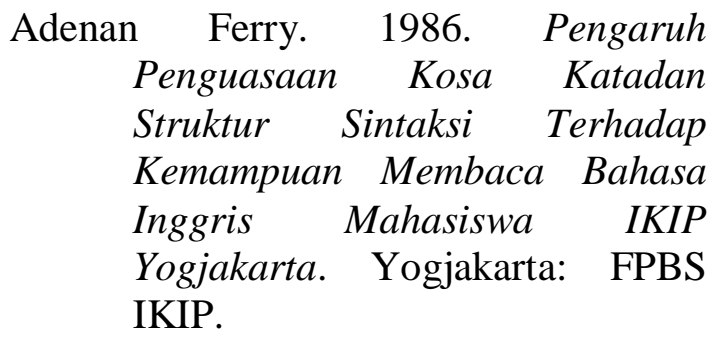

Agustiarsyahnur. 2007. Seminar Manajemen Pendidikan. Pascasarjana UNP: Padang.

Azwar S. 1997. Reliabilitas dan Validitas (Edisi III). Yogjakarta: Pustaka Belajar.

Departemen Pendidikan dan Kebudayaan. 1991b. Analisis Hasil Ebtanas SMP dan SMA Tahun 1989/1990. Jakarta Balitbangdikbud: Puslitbang Sisjian.

Departemen Pendidikan dan Kebudayaan. 1995. Kurikulum Sekolah Menengah Umum: Petunjuk Teknis Mata Pelajaran Bahasa Inggris. Jakarta.

Depdikbud. 1984/1985. Program Akta Mengajar V-B Komponen Bidang Studi Teknologi Pengajaran. Jakarta: Depdikbud Dirjen Dikti.

Gordon, T. 1997. Menjadi Guru Efektif. Jakarta: Grmedia Pustaka.

Irwanto dkk. 1997. Psikologi Umum. Jakarta: Pustaka Gramedia Utama.

Jalius Jamma. 2007. Seminar Pendidikan Kurikulum. Program Pascasarjana UNP: Padang.

Kasbolah Kasihani. 1990. Berbagai Masalah Dalam Pengajaran Bahasa Inggris di SMA. Malang: Rajawali Pustaka. 
Lado, R. 1979. Language Teaching: A Scientific Approach. New Delhi: Tata Mc-Graw-Hill Publishing Co. Ltd.

Makmur Safei. 1994. Hubungan Motivasi Belajar Dengan Prestasi Belajar Bahasa Inggris Siswa SMP. Yogjakarta: Fakultas Psikologi UGM.
Muhammad Ansyar. 2007. Pendidikan Kurikulum Indonesia. Program Pascasarjana UNP: Padang.

Prayitno. 2007. Seminar Ilmu Kependidikan. Pascasarjana UNP: Padang.

Rosydah. 1990. Strategi Komunikasi Pelajar Bahasa Kedua. Dalam NurHadi dan Roekhan (ed) Dimensi-Dimensi dalam Belajar Bahasa Kedua: Sinar Baru. 